\title{
The effect of deep eutectic solvents on the asymmetric hydrolysis of styrene oxide by mung bean epoxide hydrolases
}

Fei Peng ${ }^{1,3}$, Ying Zhao ${ }^{1,3}$, Fang-Zhou Li ${ }^{1,3}$, Min-Hua Zong ${ }^{2,3}$ and Wen-Yong Lou ${ }^{1,3^{*}}$ (1)

\begin{abstract}
Background: Deep eutectic solvents have attracted considerable attention in numerous fields. There is little information on mung bean epoxide hydrolase-catalyzed epoxides in deep eutectic solvent-containing system.

Results: Adding deep eutectic solvents with hydrogen bond donor of acids to phosphate buffer resulted in an obvious decrease in the optical purity of product; nevertheless, the relative slight change was observed by the addition of the deep eutectic solvents with hydrogen bond donor of alcohols and urea. Of the tested deep eutectic solvents, $10 \%$ additional amount of choline chloride/trithylene glycol can cause a significant improvement in the enantiopurity of product, from $83.2 \pm 1.3 \%$ to $87.9 \pm 0.3 \%$. Moreover, with the increase in the addition amount of choline chloride/ triethylene glycol from 10 to 30\%, the enantiomeric excess of product enhanced from 87.9 to $94 \%$, but a decline of product yield was observed. Finally, the evaluation of enzyme stability showed that the additional amount from 10\% to $30 \%$ was not beneficial to the activity recovery.
\end{abstract}

Conclusion: In short, adding choline chloride/triethylene glycol contributes to the improvement in the optical purity of (R)-1-phenyl-1, 2-ethanediol in the catalysis of styrene oxide by mung bean epoxide hydrolases; meanwhile, the enzyme immobilization could be essential.

Keywords: Deep eutectic solvents, Epoxide hydrolase, Styrene oxide, 1-Phenyl-1,2-ethanediol

\section{Background}

There is no doubt that chiral pure epoxides and vicinal diols have an important role in the synthesis of pharmaceuticals, pesticides and cosmetics (Hwang et al. 2008; Kotik et al. 2005; Xu et al. 2006). Glycidyl phenyl ether is a vital drug intermediate for the preparing aryloxy propanolamines (Bala et al. 2010). Among them, (S)-glycidyl phenyl ether is an important raw material for the synthesis of $\beta$-adrenergic receptor blockers by selective nucleophilic addition of amines to a single epoxide enantiomer (Gong and $\mathrm{Xu} 2005$ ). Chiral styrene glycol, namely $(S)$ or (R)-1-phenyl-1,2-ethanediol (PED), is used as a crucial and multipurpose chiral building block for synthesis of

\footnotetext{
*Correspondence: wylou@scut.edu.cn

${ }^{1}$ Laboratory of Applied Biocatalysis, School of Food Science and Engineering, South China University of Technology, Guangzhou 510640, China

Full list of author information is available at the end of the article
}

pharmaceuticals, pesticides and liquid crystal materials (Chen et al. 2012a). ( $R$ )-PED is a vital synthon for the synthesis of chiral $\beta$-adrenergic receptor blockers, antiarrhythmic drugs, and (S)-PED can be employed for the synthesis of production of chiral bisphosphines and the chiral initiator of selective polymerization (Nie et al. 2004). In many methods for the synthesis of vicinal diols, epoxide hydrolases are often applied to catalyze the asymmetric hydrolysis of epoxides because of economy and convenience (Yu et al. 2013). However, the poor solubility of epoxides in aqueous buffer system is the general issue due to the lipophilic oxiranes (Simeó and Faber 2006). In addition, another disadvantageous for the asymmetric hydrolysis of epoxides is that epoxides are susceptible to non-enzymatic hydrolysis, resulting in low enantiomeric purity or yield of the product (Chen et al. 2012b). To overcome the above shortcomings, organic solvents and co-solvents are used in the catalysis of 
epoxides to vicinal diols. For example, compared to an aqueous monophasic system, a biphasic reaction system composed of $n$-hexane and phosphate buffer not only controlled the non-enzymatic hydrolysis of styrene oxide (SO) achieving better optical purity of the product, but also increased the maximum reaction concentration of the substrate from 5 to $20 \mathrm{mM}$ (Chen et al. 2011, 2012b). At the same time, adding a small amount of hydrophilic ionic liquid as co-solvent can increase the stability of the mung bean epoxide hydrolases ( $\mathrm{mEHs}$ ) and the solubility of the reaction substrate in the buffer (Chen et al. 2011, 2012b). However, there are certain industrial restrictions on the use of organic solvents as reaction solvents because of volatility and toxicity. To overcome the drawbacks of organic solvents, deep eutectic solvents (DESs) as new green solvents have emerged at early this century.

Over decades, many studies have shown that the conventional ionic liquids, with excellent properties, such as low melting point, less volatility and preferable biocompatibility, can be used for biocatalytic reaction to obtain better product yield and purity. DESs are generally the molten liquids by the hydrogen bond interaction among two or three relatively cheap and safe components (Lu et al. 2016; Flores-Ferrándiz and Chinchilla 2017; Zhang et al. 2012). Up to now, DESs have exhibited their application potential because of the advantages of low cost, environmental friendliness, low vapor pressure, low melting point and easy degradation (Flores-Ferrándiz and Chinchilla 2017; Lobo et al. 2012a, b). In fact, many reports have shown that deep eutectic solvents can be employed in dissolution and separation (Lu et al. 2016; Radošević et al. 2016), organic synthesis (Gore et al. 2011), electrochemistry (Zhang et al. 2012) and catalytic reactions (Cao et al. 2016; Gorke et al. 2008; Harifi-Mood et al. 2017; Xu et al. 2015a; Yang and Duan 2016). DESs can be used as not only the co-solvent but also the main reaction medium. With addition of choline chloride/ethylene glycol, choline chloride/glycerol and $N, N$-diethyl ethanol ammonium chloride/ethylene glycol in the volume ratio of $40 \%$, the activity of lipase for the hydrolysis of $p$-nitrophenyl palmitate to $p$-nitrophenol was increased by 230, 180 and 170\%, respectively (Juneidi et al. 2017). In addition, lipase catalyzed the above reaction with enhancement of 2.6 times in the activity in the presence of choline/ethylene glycol containing $4 \%$ water than phosphate buffer (Juneidi et al. 2017). Another work has shown that the presence of water is important to increase activity and conversion in a reaction (Guajardo et al. 2017). In 2010, Lindberg et al. (2010) testified that DESs were beneficial for increasing substrate concentrates and enhancing the regioselectivity of potato epoxide hydrolase. However, to this day, no information on the hydrolysis of styrene oxide (SO) to (R)-PED by $\mathrm{mEHs}$ in the solution containing DESs was reported. Therefore, in the study, we described

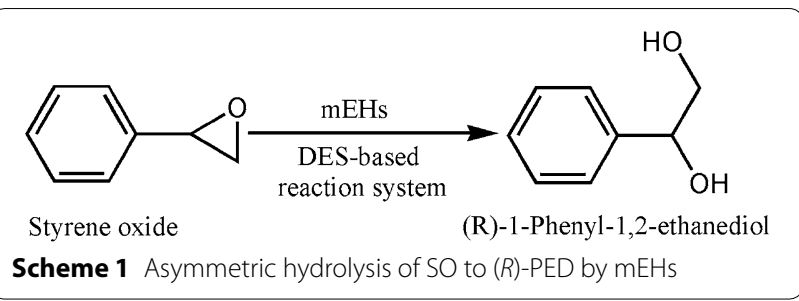

the effect of several DESs on the synthesis of (R)-PED from SO by mEHs (shown in Scheme 1).

\section{Methods \\ Materials}

Mung beans were purchased from a local supermarket in Guangzhou. Racemic PED and SO were purchased from Guangzhou Qiyun bioscience Co. Ltd. All other reagents used to synthesize DESs were of analytical grade and were from commercial sources. The preparation of DESs was referenced by previous literature (Zhao et al. 2015). Briefly, choline chloride and hydrogen bond donor were mixed at a fixed molar ratio at $80{ }^{\circ} \mathrm{C}$ for appropriately $2 \mathrm{~h}$ until the formation of a stable homogeneous liquid. All DESs were further dried in a vacuum oven at $70^{\circ} \mathrm{C}$ for $48 \mathrm{~h}$.

\section{Preparation and activity assay of crude mEHs}

According to previous publications with suitable modification (Chen et al. 2012a, b), the mung beans (100 g) were ground to a fine paste after soaked in distilled water $(1 \mathrm{~L})$ for $12 \mathrm{~h}$ and peeled. The paste was then suspended in $300 \mathrm{~mL}$ Tris- $\mathrm{HCl}$ buffer $(50 \mathrm{mM}, \mathrm{pH} 7.0)$ and stirred at $0{ }^{\circ} \mathrm{C}$ for $1 \mathrm{~h}$. Next, the suspension was centrifuged $\left(7900 \mathrm{rpm}, 4^{\circ} \mathrm{C}\right)$ for $30 \mathrm{~min}$ and the sediment was discarded. Actamaster $(49.2 \mathrm{~g})$ was added to the supernatant at a gradual rate. After stirring at $0{ }^{\circ} \mathrm{C}$ for $20 \mathrm{~min}$ and standing for $30 \mathrm{~min}$, the mixture was centrifuged $\left(7900 \mathrm{rpm}, 4^{\circ} \mathrm{C}\right)$ for $30 \mathrm{~min}$ and the sediment was discarded. The operation of adding actamaster ( $33.2 \mathrm{~g}$ ) was repeated. Finally, the yellow sediment was achieved, and some Tris- $\mathrm{HCl}$ was added to the sediment to obtain the enzyme suspension.

The activity of enzyme was defined as the amount of enzyme to produce $1 \mu \mathrm{moL}$ PED in a minute. The above enzyme liquid $(50 \mu \mathrm{L})$ prepared was added to phosphate buffer $(100 \mathrm{mM}, \mathrm{pH} 6.5,3.95 \mathrm{~mL})$, following addition of SO (5 mM, final concentration) to start the reaction. After catalyzing for $15 \mathrm{~min}$, samples were withdrawn and addition of hexane was used for wiping off the residual SO because of none-enzymatic hydrolysis. The amount of PED was determined using high-performance liquid chromatography (HPLC).

\section{Effect of various DESs on mEHs-catalyzed SO}

In the typical experiment, $4 \mathrm{~mL}$ of DES-buffer reaction system was consisted of phosphate buffer $(3.0 \mathrm{~mL}$, 
$100 \mathrm{mM}, \mathrm{pH}$ 6.5), DES (0.4 mL) and enzyme liquid $(0.6 \mathrm{~mL}, 1.92 \mathrm{U})$. The injection of SO $(5 \mathrm{mM}$, final concentration) triggered the reaction after DES-buffer system incubated for $15 \mathrm{~min}$ in a water-bath shaker. The catalytical reaction was conducted at $35{ }^{\circ} \mathrm{C}, 180 \mathrm{rpm}$. Periodically, samples were withdrawn to analyze enantiopurity and yield of product.

The non-enzymatic hydrolysis rate of $\mathrm{SO}$ was determined after incubation at $35^{\circ} \mathrm{C}, 180 \mathrm{rpm}$ for $1 \mathrm{~h}$ in $4 \mathrm{~mL}$ of enzyme-free systems, which $\mathrm{pH}$ was also measured by $\mathrm{pH}$ meter. The enzyme-free systems $(4 \mathrm{~mL})$ contained phosphate buffer (100 mM, pH 6.5), Tris-HCl buffer (0.6 mL, $50 \mathrm{mM}, \mathrm{pH} 7.0)$ and DESs $(0$ or $0.4 \mathrm{~mL})$.

\section{Asymmetric hydrolysis of $\mathrm{SO}$ and stability of $\mathrm{mEHs}$ in various $\mathrm{ChCl} / \mathrm{TEG}$ concentrations}

The impact of $\mathrm{ChCl} / \mathrm{TEG}$ at the concentrations varied from 10 to $40 \%(\mathrm{v} / \mathrm{v})$ on the asymmetric hydrolysis of SO by $\mathrm{mEHs}$ was investigated. In short, injection of SO $(5 \mathrm{mM})$ started the reactions at $35^{\circ} \mathrm{C}$ and $180 \mathrm{rpm}$ after the previously prepared reaction systems reached to $35^{\circ} \mathrm{C}$. Periodically, samples were taken for analysis of enantiopurity and yield of product.

The reservation in the activity of $\mathrm{mEHs}$-catalyzed $\mathrm{SO}$ was used to evaluate the effect of $\mathrm{ChCl} / \mathrm{TEG}$ on the stability of enzyme. In short, $0.6 \mathrm{~mL} \mathrm{mEHs}$ solution was added to $3.4 \mathrm{~mL}$ phosphate buffer containing various concentrations of $\mathrm{ChCl} / \mathrm{TEG}$ and the mixtures were incubated for 0 or $12 \mathrm{~h}$ at $35^{\circ} \mathrm{C}, 180 \mathrm{rpm}$. Then, SO $(5 \mathrm{mM}$, final concentration) was injected into the systems to trigger the reaction. After $15 \mathrm{~min}$, samples were taken for analyzing the activation of crude enzyme liquid by HPLC.

\section{Analytical methods}

Analysis on the enantiopurity of product was carried out using a Shimadzu 2010 GC equipped with a flame ionization detector and a chiral column, 10\% permethylated $\beta$-cyclodextrin ( $30 \mathrm{~m} \times 0.25 \mathrm{~mm}$, Hewlett-Packard, USA). Its concentration was analyzed by Waters 1525 HPLC equipped with a UV detector at $215 \mathrm{~nm}$. The column was a Zorbax Extend-C18 column $(4.6 \mathrm{~mm} \times 250 \mathrm{~mm}, 5 \mu \mathrm{m}$, Agilent, USA) kept temperature at $35{ }^{\circ} \mathrm{C}$. An isocratic elution was used, water and methanol $(70 / 30, \mathrm{v} / \mathrm{v})$ with a flow rate of $0.5 \mathrm{~mL} / \mathrm{min}$. All experiments were conducted at least in duplicate, and the values were expressed as the mean \pm standard error.

\section{Results and discussion}

The effects of different DESs on the asymmetric hydrolysis of SO

We tested the effect of DESs-based on $\mathrm{ChCl}$ and different hydrogen bond donors on the asymmetric hydrolysis of $\mathrm{SO}$ because of the exciting results with addition of DESs in biocatalysis, for example, higher enantioselectivity and yield of product. As shown in Table 1, the comparative excellent enantiopurities of product were obtained when the DESs, except those using acids as hydrogen bond donor, were added as co-solvent in the phosphate buffer. In addition, there was a slight difference in yield of $(R)$-PED in the systems containing DESs. We further measured the $\mathrm{pH}$ of DESs-containing buffer (shown in Fig. 1), for the poor enantiopurity of (R)-PED when acids were used as hydrogen bond donor. Significant decrease in $\mathrm{pH}$ values and rapid non-enzymatic hydrolysis of $\mathrm{SO}$ were observed after addition of $10 \%$ DESs using acids as

\begin{tabular}{|c|c|c|c|}
\hline DESs & $\begin{array}{l}\text { Salt/HBD } \\
\text { molar ratio }\end{array}$ & Product e.e. (\%) & $\begin{array}{l}\text { Product yield } \\
\text { (\%) }\end{array}$ \\
\hline Phosphate buffer & 1 & $83.2 \pm 1.3$ & $46.8 \pm 1.7$ \\
\hline $\mathrm{ChCl} /$ urea & $1: 2$ & $84.7 \pm 0.4$ & $45.0 \pm 0.4$ \\
\hline $\begin{array}{l}\text { ChCl/ethylene } \\
\text { glycol }\end{array}$ & $1: 2$ & $82.5 \pm 1.1$ & $44.0 \pm 1.5$ \\
\hline $\mathrm{ChCl} /$ glycerol & $1: 2$ & $82.2 \pm 1.5$ & $43.6 \pm 1.6$ \\
\hline $\begin{array}{l}\mathrm{ChCl} / 1,4 \text {-butan- } \\
\text { ediol }\end{array}$ & $1: 4$ & $69.5 \pm 6.8$ & $44.3 \pm 0.6$ \\
\hline $\begin{array}{l}\text { ChCl/triethylene } \\
\text { glycol }\end{array}$ & $1: 4$ & $87.9 \pm 0.3$ & $44.9 \pm 0.6$ \\
\hline $\mathrm{ChCl} /$ oxalic acid & $1: 1$ & $4.8 \pm 2.3$ & 1 \\
\hline $\begin{array}{l}\mathrm{ChCl} / \text { levulinic } \\
\text { acid }\end{array}$ & $1: 2$ & $4.0 \pm 1.9$ & 1 \\
\hline $\begin{array}{l}\mathrm{ChCl} / \text { malonic } \\
\text { acid }\end{array}$ & $1: 1$ & $3.5 \pm 2.8$ & 1 \\
\hline $\mathrm{ChCl} / \mathrm{malic}$ acid & $1: 1$ & 1 & 1 \\
\hline $\mathrm{ChCl} /$ citric acid & $1: 1$ & $\backslash$ & 1 \\
\hline
\end{tabular}

ChCl: choline chloride; \: no determinations

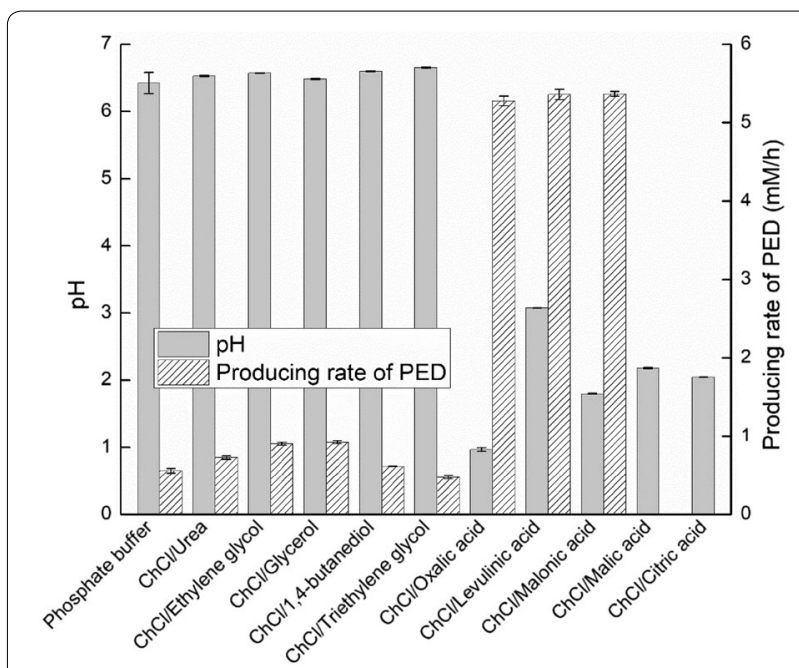

Fig. 1 Effect of various DESs on pH of buffers and non-enzymatic hydrolysis of $\mathrm{SO}$ 
hydrogen bond donor to the phosphate buffer $(100 \mathrm{mM}$, $\mathrm{pH}$ 6.5). Hence, we believed that the main reasons causing unpromising enantiopurity of $(R)$-PED when using these acid DESs as co-solvent were easily none-enzymatic hydrolysis of $\mathrm{SO}$ and deactivation of enzyme at low $\mathrm{pH}$ value. Similarly, using red mung bean epoxide hydrolase for stereoselectivity catalysis of racemic SO to $(R)$-PED achieved an obvious decease in conversion from more than $40 \%$ at pH 7.5 to less than $30 \%$ at $\mathrm{pH} 6.0$ because of deactivation of the enzyme (Kamble and Yadav 2017). Thus, DESs consisting of acids as HBD could be unsuitable for biocatalysis because of low $\mathrm{pH}$, which is enough to cause inactivation of the biocatalyst.

In the presence of DESs with urea and polyols as HBD except $\mathrm{ChCl} / 1,4$-butanediol, optical purity of (R)-PED had slight difference from that in the DES-free system, and slight higher enantiopurities of (R)-PED were obtained when using $\mathrm{ChCl} /$ urea or $\mathrm{ChCl} / \mathrm{TEG}$ as the co-solvent. Similarly, the addition of DESs using urea and polyols as hydrogen bond donor to phosphate buffer lead to slight changes in $\mathrm{pH}$ value (pH 6.48-6.65 vs $\mathrm{pH} 6.42$ ). In addition, the comparatively slight changes $(0.48-0.92 \mathrm{mM} / \mathrm{h}$ vs $0.56 \mathrm{mM} / \mathrm{h}$ ) in non-enzymatic hydrolysis of epoxide were displayed in DES-containing solutions with urea or polyols as HBD. The results above, for the tested DESs, indicate that non-enzymatic hydrolysis of the epoxide in DES-containing buffer depends on not only the $\mathrm{pH}$ of reaction system but also the co-solvent of DES. For instance, the improvement in the solubility of SO was observed after adding small amount of co-solvent so as to inhibit the natural hydrolysis of the substrate (Chen et al. 2011). Besides, the hydrophily of DESs allows them to structurally tie up water molecules to change catalytically active confirmation of enzyme (Zhao et al. 2011).

\section{The effects of DES concentration on epoxide catalysis by $\mathrm{mEHs}$}

Similar to ionic liquids, DESs can affect structure and function of biomolecules, for example, by hydrogen bond, polarity and hydrophily, so that change their activities. With the increase of DES concentration, the change in tertiary and secondary structure of beef liver catalase leads to the decrease of activity (Harifi-Mood et al. 2017).

In the further work, we studied the effect of $\mathrm{ChCl} /$ TEG concentrations on the yield and enantiopurity of (R)-PED by the asymmetric hydrolysis of SO because of a slightly better optical purity of the product achieved. As illustrated in Fig. 2a, there was no significant difference in the initial reaction rate among DES concentrations tested from 10 to $30 \%$. However, the decrease in the yield of product was observed with the increase in $\mathrm{ChCl} / \mathrm{TEG}$ concentration. In comparison to the phosphate buffer without DES, addition of $10 \% \mathrm{ChCl} / \mathrm{TEG}$ caused slight

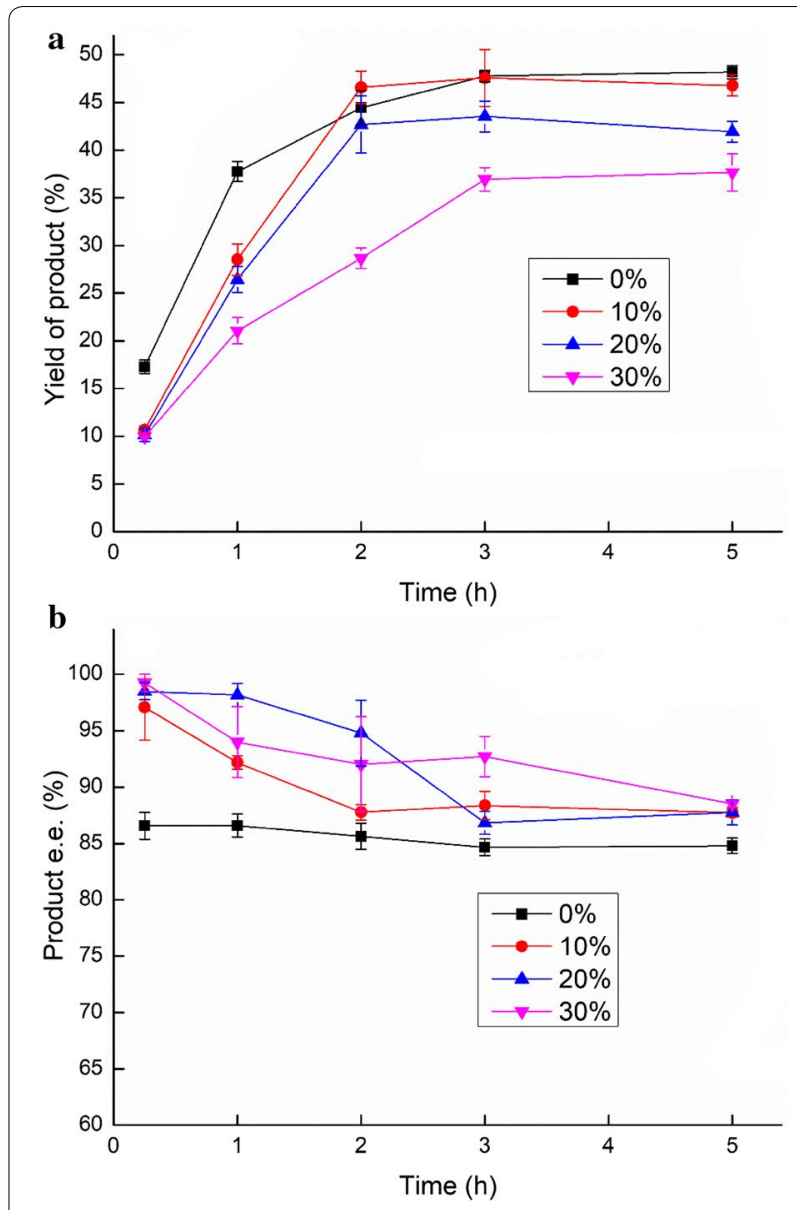

Fig. 2 Effect of the volume ratio of $\mathrm{ChCl} / \mathrm{TEG}$ to buffer on mEHscatalyzed asymmetric hydrolysis of SO. a Yield of product; $\mathbf{b}$ product e.e. value

difference in the yield of product even better yield. Moreover, $30 \%$ of DES as co-solvent resulted in a prolonged reaction time. These results suggest that low dosage of $\mathrm{ChCl} / \mathrm{TEG}$, such as $10 \%$, has slight impact on the activity of $\mathrm{mEHs}$, and excessive dosage of $\mathrm{ChCl} / \mathrm{TEG}$ has a negative effect on the activity of mEHs.

As depicted in Fig. 2b, injection of the DES in various concentrations tested was beneficial for improving the product optical purity. After $2 \mathrm{~h}$ of catalytical reaction, a highest enantiopurity of $94 \%$ was achieved in the reaction system containing $20 \%$ of $\mathrm{ChCl} / \mathrm{TEG}$. Further increasing the concentration of DES leaded to a slightly poor optical purity of product ( $92 \%$ at $3 \mathrm{~h}$ ). The slightly lower enantiopurity of product could be accounted for a subtle change in the microenvironment of enzyme. In addition, the enantiopurity of the product decreased with the prolongation of reaction time in DES-containing solutions tested, likely due to non-enzymatic hydrolysis of SO. 


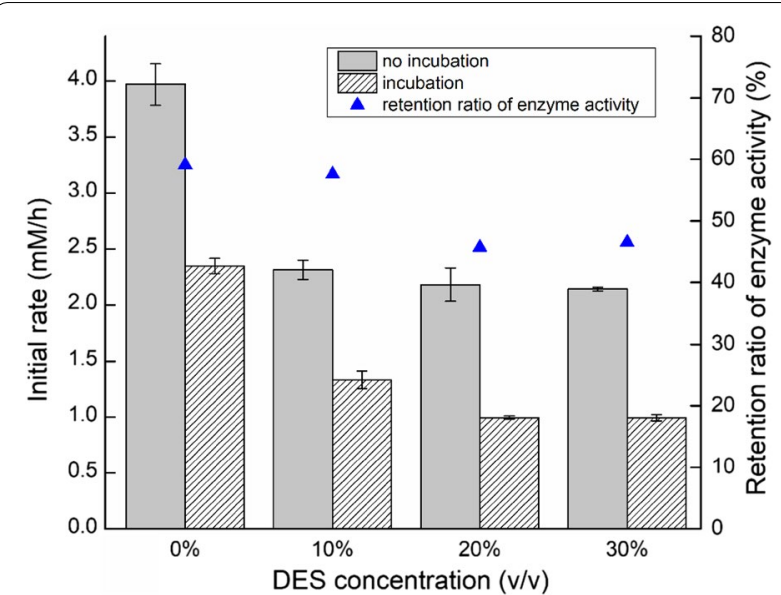

Fig. 3 Effect of the volume ratio of $\mathrm{CHCl} / \mathrm{TEG}$ to buffer on activity and stability of $\mathrm{mEHs-catalyzed} \mathrm{asymmetric} \mathrm{hydrolysis} \mathrm{of} \mathrm{SO}$

Compared to other publications using DES as co-solvent in the biocatalysis, many delightful results exerted on the improvement of reaction rate, not the enantioselectivity. For instance, Gorke et al. (2008) reported that the co-solvent $\mathrm{DES}(\mathrm{ChCl} /$ glycerol) had a great influence on the activity but not on the enantioselectivity in the catalysis of styrene oxide by epoxide hydrolase. Moreover, our previous work also indicated that the addition of $\mathrm{DES}, \mathrm{ChCl} /$ urea, can improve the catalytic activity of Acetobacter sp. CCTCC $\mathrm{m} 209061$ in the 3-chloropropiophenone to (S)-3-chloro-1-phenylpropanol (Xu et al. 2015b). However, in the present work, an increase in the concentration of DES favored enantioselectivity of mEHs, but decreased the performance of the reaction, suggesting there was a compromise between yield and enantioselectivity.

\section{The effects of DES on the activity of enzyme}

Previous publication described that, in all ChCl-based DES aqueous systems, horseradish peroxidase at low DES concentration keeps as actively as in the DES-free solution. And further study on circular dichroism spectroscopy proved that DESs examined were able to increase $\alpha$-helix content for the enzyme so as to improve its stability (Wu et al. 2014).

The changes in activity of $\mathrm{mEHs}$ were displayed in various concentrations of DES (shown in Fig. 3). The activity of mEHs-catalyzed SO to (R)-PED markedly dropped when adding DES to aqueous solution in no incubation group and a further decrease in the activity of mEHs was observed after $6 \mathrm{~h}$ of incubation. Calculably, the remaining activity of mEHs decreased with the increase of $\mathrm{ChCl} /$ TEG concentration after $6 \mathrm{~h}$ of incubation. The results suggest that the co-solvent of $\mathrm{ChCl} / \mathrm{TEG}$ exerts a negative effect on the activity and stability of $\mathrm{mEHs}$. Likewise, the increase in DES concentration lead to decrease of the half-lives of potato epoxide hydrolase activity (Lindberg et al. 2010).

\section{Conclusions}

We have investigated the effect of various DESs on asymmetric hydrolysis of styrene oxide to $(R)$-phenyl glycol by mung bean epoxide hydrolases. A disadvantage of DESs using acids as hydrogen bond donor limits DESs' application in the catalysis of epoxides even in other biosynthesis because of comparative strong acidity. An improvement of enantiopurity of $(R)$-PED by the asymmetric hydrolysis of $\mathrm{SO}$, using $\mathrm{mEHs}$ as biocatalyst, can be achieved with the phosphate buffer containing low level of $\mathrm{ChCl} / \mathrm{TEG}$, such as $10-20 \%$. Also, $\mathrm{ChCl} / \mathrm{TEG}$ has a negative effect on the stability of $\mathrm{mEHs}$. We suggested that the future work could be focused on the improvement of $\mathrm{mEHs}$ stability. Further works could focus on the introduction of immobilization technology to enhance the stability of enzyme.

\section{Abbreviations}

DESs: deep eutectic solvents; ChCl/TEG: choline chloride/triethylene glycol; e.e.: enantiomeric excess; HBD: hydrogen bond donor; PED: 1-phenyl-

1,2-ethanediol; $\mathrm{mEH}$ s: mung bean epoxide hydrolases; SO: styrene oxide.

\section{Authors' contributions}

Conceived and designed the experiments: FP, WYL, MHZ. Performed the experiments: FP and YZ. Analyzed the data: FP and YZ. Wrote the paper: FP, WYL and FZL. All authors read and approved the final manuscript.

\section{Author details \\ ${ }^{1}$ Laboratory of Applied Biocatalysis, School of Food Science and Engineering, South China University of Technology, Guangzhou 510640, China. ${ }^{2}$ State Key Laboratory of Pulp and Paper Engineering, South China University of Tech- nology, Guangzhou 510640, China. ${ }^{3}$ Guangdong Province Key Laboratory for Green Processing of Natural Products and Product Safety, South China University of Technology, Guangzhou 510640, China.}

\section{Acknowledgements}

Not applicable.

\section{Competing interests}

The authors declare that they have no competing interests.

Availability of data and materials

All data generated or analyzed during this study are included in this article.

\section{Consent for publication}

All of authors have read and approved to submit it to Bioresources and Bioprocessing.

\section{Ethics approval and consent to participate}

Not applicable.

\section{Funding}

We wish to thank the National Natural Science Foundation of China $(21676104 ; 21336002 ; 21376096)$, the Open Funding Project of the State Key Laboratory of Bioreactor Engineering, and the Program of State Key Laboratory of Pulp and Paper Engineering (2017ZD05) for partially funding this work. 


\section{Publisher's Note}

Springer Nature remains neutral with regard to jurisdictional claims in published maps and institutional affiliations.

Received: 11 October 2017 Accepted: 31 January 2018

Published online: 08 February 2018

\section{References}

Bala N, Chimni SS, Saini HS, Chadha BS (2010) Bacillus alcalophilus MTCC10234 catalyzed enantioselective kinetic resolution of aryl glycidyl ethers. J Mol Catal B Enzym 63:128-134

Cao SL, Yue DM, Li XH, Smith TJ, Li N, Zong MH, Lou WY (2016) Novel nano-/ micro-biocatalyst: soybean epoxide hydrolase immobilized on UiO66-NH2 MOF for efficient biosynthesis of enantiopure (R)-1,2-octanediol in deep eutectic solvents. ACS Sustain Chem Eng 4:3586-3595

Chen WJ, Lou WY, Wang X, Zong MH (2011) Asymmetric hydrolysis of styrene oxide catalyzed by mung bean epoxide hydrolase in organic solvent/ buffer biphasic system. Chin I Catal 32:1557-1563

Chen WJ, Lou WY, Zong MH (2012a) Efficient asymmetric hydrolysis of styrene oxide catalyzed by mung bean epoxide hydrolases in ionic liquid-based biphasic systems. Bioresour Technol 115:58-62

Chen WJ, Lou WY, Yu CY, Wu H, Zong MH, Smith TJ (2012b) Use of hydrophilic ionic liquids in a two-phase system to improve mung bean epoxide hydrolases-mediated asymmetric hydrolysis of styrene oxide. J Biotechnol 162:183-190

Flores-Ferrándiz J, Chinchilla R (2017) Organocatalytic enantioselective conjugate addition of aldehydes to maleimides in deep eutectic solvents. Tetrahedron Asymmetry 28:302-306

Gong PF, Xu JH (2005) Bio-resolution of a chiral epoxide using whole cells of Bacillus megaterium ECU1001 in a biphasic system. Enzym Microb Technol 36:252-257

Gore S, Baskaran S, Koenig B (2011) Efficient synthesis of 3, 4-dihydropyrimidin-2-ones in low melting tartaric acid-urea mixtures. Green Chem 13:1009-1013

Gorke JT, Srienc F, Kazlauskas RJ (2008) Hydrolase-catalyzed biotransformations in deep eutectic solvents. Chem Commun 10:1235-1237

Guajardo N, Domínguez de María P, Ahumada K, Schrebler RA, Ramírez-Tagle R, Crespo FA, Carlesi C (2017) Water as cosolvent: nonviscous deep eutectic solvents for efficient lipase-catalyzed esterifications. ChemCatChem 9(8):1393-1396

Harifi-Mood AR, Ghobadi R, Divsalar A (2017) The effect of deep eutectic solvents on catalytic function and structure of bovine liver catalase. Int J Biol Macromol 95:115-120

Hwang S, Choi CY, Lee EY (2008) Enantioconvergent bioconversion of $p$-chlorostyrene oxide to (R)-p-chlorophenyl-1,2-ethandiol by the bacterial epoxide hydrolase of Caulobacter crescentus. Biotechnol Lett 30:1219-1225

Juneidi I, Hayyan M, Hashim MA, Hayyan A (2017) Pure and aqueous deep eutectic solvents for a lipase-catalysed hydrolysis reaction. Biochem Eng J 117:129-138

Kamble MP, Yadav GD (2017) Biocatalytic resolution of (R, S)-styrene oxide using a novel epoxide hydrolase from red mung beans. Catal Today. https://doi.org/10.1016/j.cattod.2017.06.013

Kotik M, Brichac J, Kyslík P (2005) Novel microbial epoxide hydrolases for biohydrolysis of glycidyl derivatives. J Biotechnol 120:364-375
Lindberg D, de la Fuente Revenga M, Widersten M (2010) Deep eutectic solvents (DESs) are viable cosolvents for enzyme-catalyzed epoxide hydrolysis. J Biotechnol 147:169-171

Lobo HR, Singh BS, Shankarling GS (2012a) Deep eutectic solvents and glycerol: a simple, environmentally benign and efficient catalyst/reaction media for synthesis of $\mathrm{N}$-aryl phthalimide derivatives. Green Chem Lett Rev 5(4):487-533

Lobo HR, Singh BS, Shankarling GS (2012b) Lipase and deep eutectic mixture catalyzed efficient synthesis of thiazoles in water at room temperature. Catal Lett 142(11):1369-1375

Lu W, Alam MA, Pan Y, Wu J, Wang Z, Yuan Z (2016) A new approach of microalgal biomass pretreatment using deep eutectic solvents for enhanced lipid recovery for biodiesel production. Bioresour Technol 218:123-128

Nie Y, Xu Y, Mu XQ (2004) Highly enantioselective conversion of racemic 1-phenyl-1,2-ethanediol by stereoinversion involving a novel cofactordependent oxidoreduction system of Candida parapsilosis CCTCC M203011. Org Process Res Dev 8:246-251

Radošević K, Ćurko N, Srček VG, Bubalo MC, Tomašević M, Ganić KK, Redovniković IR (2016) Natural deep eutectic solvents as beneficial extractants for enhancement of plant extracts bioactivity. LWT Food Sci Technol 73:45-51

Simeó Y, Faber K (2006) Selectivity enhancement of enantio- and stereo-complementary epoxide hydrolases and chemo-enzymatic deracemization of $( \pm)$-2-methylglycidyl benzyl ether. Tetrahedron Asymmetry 17:402-409

Wu BP, Wen Q, Xu H, Yang Z (2014) Insights into the impact of deep eutectic solvents on horseradish peroxidase: activity, stability and structure. J Mol Catal B Enzym 101:101-107

Xu W, Xu JH, Pan J, Gu Q, Wu XY (2006) Enantioconvergent hydrolysis of styrene epoxides by newly discovered epoxide hydrolases in mung bean. Org Lett 8:1737-1740

Xu P, Cheng J, Lou WY, Zong MH (2015a) Using deep eutectic solvents to improve the resolution of racemic 1-(4-methoxyphenyl) ethanol through Acetobacter sp. CCTCC M209061 cell-mediated asymmetric oxidation. RSC Adv 5:6357-6364

Xu P, Xu Y, Li XF, Zhao BY, Zong MH, Lou WY (2015b) Enhancing asymmetric reduction of 3-chloropropiophenone with immobilized Acetobacter sp. CCTCC M209061 cells by using deep eutectic solvents as cosolvents. ACS Sustain Chem Eng 3:718-724

Yang SL, Duan ZQ (2016) Insight into enzymatic synthesis of phosphatidylserine in deep eutectic solvents. Catal Commun 82:16-19

Yu CY, Li XF, Lou WY, Zong MH (2013) Cross-linked enzyme aggregates of mung bean epoxide hydrolases: a highly active, stable and recyclable biocatalyst for asymmetric hydrolysis of epoxides. J Biotechnol 166:12-19

Zhang Q, Vigier KDO, Royer S, Jérôme F (2012) Deep eutectic solvents: syntheses, properties and applications. Chem Soc Rev 41:7108-7146

Zhao H, Baker GA, Holmes S (2011) Protease activation in glycerol-based deep eutectic solvents. J Mol Catal B Enzym 72:163-167

Zhao BY, Xu P, Yang FX, Wu H, Zong MH, Lou WY (2015) Biocompatible deep eutectic solvents based on choline chloride: characterization and application to the extraction of rutin from Sophora japonica. ACS Sustain Chem Eng 3:2746-2755

\section{Submit your manuscript to a SpringerOpen ${ }^{\circ}$ journal and benefit from:}

- Convenient online submission

- Rigorous peer review

- Open access: articles freely available online

- High visibility within the field

- Retaining the copyright to your article

Submit your next manuscript at $\boldsymbol{\nabla}$ springeropen.com 